\title{
Mangroves in India: A Unique Marine Ecosystem
}

\author{
A. Arunprasath, M. Gomathinayagam \\ Department of Botany, Annamalai University, Annamalainagar-608 002 Tamilnadu, India \\ E-mail address: arunprasath194@gmail.com
}

\section{Keywords: Mangroves in India; Marine Ecosystem}

\section{ABSTRACT}

India has a long tradition of mangrove forest management. The Sundarb ns man ves, located in the Bay of Bengal (partly in India and partly in Bangladesh), were the tongro in the world to be put under scientific management. The area's first mage, plan was implemented in 1892. Recognizing the importance of mangroves, the Go ernment or ria set up the National Mangrove Committee in the Ministry of Environment and F sts in 976 to dvise the government about mangrove conservation and development. In its $f$ ing, the anel, which consists of scientists, research scholars and experts on the mang ve ecosy $n$, omphasized the need to conduct a survey of the extent of existing mangrove are

\section{INTRODUCTION}

Mangrove forests are one of the most producti and bio di erse wetlands on earth. They may be disappearing more quickly than inland tropica infores s, and so far, with little public notice. Growing in the inter-tidal areas and ary moutro oetween land and sea, mangroves provide critical habitat for a diverse marine ha mial flora and fauna. Healthy mangrove forests are key to a healthy marine ecology. The orovid a rich natural habitat and safe breeding grounds for several fish species. Ser also $f$ d safe nesting and egg laying areas in the vast mangrove forests of the country they event th coastline erosion caused by waves and ocean currents. In the past, mangroy wo source of food and fuel, and was also used for building houses and ships bo cause of ardness and high resistance to rot and termites.

\section{WORLD LEY DIS TIBUTKON}

Mangroves occupy less tha $1 \%$ of the world's surface and are mainly found between the Tropic of Canc and th Tropic of Capricorn on all continents covering an estimated 75 percent of the tropical coast. vorldwi $\mathrm{e}$. There are more than 18 million ha of global mangroves inhabiting in $112 \mathrm{co}$ an an trito ies in the tropical and subtropical region. Around 34 major and 20 minor nangr e specr belonging to about 20 genera in over 11 families have been recorded globan

\section{Dist ion of mangrove in India}

India with a long coastline of about $7516.6 \mathrm{~km}$, including the island territories has a mangrove cover of about $6,749 \mathrm{~km}$, the fourth largest mangrove area in the world. These mangrove habitats comprise three distinct zones: East coast habitats having a coast line of about $2700 \mathrm{~km}$, facing Bay of Bengal, West coast habitats with a coast line of about $3000 \mathrm{~km}$, facing Arabian sea, and Island Territories with about $1816.6 \mathrm{~km}$ coastline. In India, the states like West Bengal, Orissa, Andhra Pradesh, Tamil Nadu, Andaman and Nicobar Islands, Kerala, Goa, Maharashtra, and Gujarat occupy vast area of Mangroves. The area under mangroves in Gujarat is the second largest along the Indian coast, after Sunderbans. Mangroves in India account for about 3\% of the global mangroves and $8 \%$ of Asian mangroves. About $60 \%$ of the mangroves occur on the east coast along the Bay of Bengal, 27\% on the west coast bordering the Arabian Sea, and 13\% on Andaman \& 
Nicobar Islands. Mangrove area is larger in the east coast of India around $80 \%$ as to $20 \%$ in the west coast owing to the terrain and slope and due to the river deltas of Ganges, Brahmaputra, Mahanadi, Godavari, Krishna and Cauvery which have nutrient rich alluvial soil. 60 species of mangroves are known to grow abundantly. The Sundarbans(east coast) covering about 9,600 sq. $\mathrm{km}$ of mangrove forest and water comprises essentially of numerous islands formed by the sediments deposited by three major rivers, the Ganga, Brahmaputra and the Meghna, and a dense network of smaller rivers, channels and creeks. The mangrove area in Orissa is nearly $200 \mathrm{~km}$ in extant and its degradation is placed at $20 \mathrm{~km}$ over ten years, as per recent estimates. Andhra Pradesh possesses about $582 \mathrm{~km}$ of mangrove area. Tami Nadu is one of the nine maritime states of India endowed with the second longest coastline of $1.076 \mathrm{~km}$.

The major mangrove wetlands in Tamil Nadu are Pichavaram mangroves and $M_{1 y}$ thupet mangroves, for which river Cauvery is the main supplier of freshwater. The area ider m rove ecosystem in Tamil Nadu is about $225 \mathrm{~km}$. mangrove wetlands of Orissa have thest nu ber of species followed by Sunderbans of West Bengal and Andaman and Nicobrvislà The I lian mangroves comprise approximately 59 species in 41 genera and 29 famil os. Of thes 4 s, secies belonging to 25 genera and 21 families are present along west coast imila there re eight species of mangroves like Sonneratia caseolaris, Suaeda fruticosa, $U$ ch a setuld etc. which have been reported only from the west coast. There are appr ximately mar grove species reported from the Gujarat coast, while Maharashtra has abor species, $/ 14$ species and Karnataka 10. The associated mangrove flora is quite can fon 11 the coasts, with minor variations in distribution. The floral diversity of mang oves of India comprised of 38 core mangrove species. Analysis of the distribution of ae mangrove species in different Indian mangrove wetlands indicates that Acanthus iiicifolius, legiceras co niculatum, Avicennia marina, Bruguiera cylindrica, Ceriops decandra, Excoecaria $a_{8}$ 'ocha, Lu hnitzera racemosa, Rhizophora apiculata, R. mucronata are common to all themangroves an the other hand, species such as Pemphis asidula is endemic to islands of Mannar of Tamil Nadu, Scyphiphora hydrophyllacea to Godavari mangroves of An hra frum. Similarly, Nypa fruticans has been reported to be present only in Sunderhans of est Bengal. The Tamil Nadu mangrove is also characterized by the presence of a y ara ybrid o Rhizophora species.

\section{THREATS TO MAV 30 WCONATEM}

The threats to the arove eco could be broadly grouped into two: Natural and Anthropogenic. These ctors $\mathrm{V}$ affect he system as a whole or any one entity within the system, etc. The natural tb cons includo linatic changes, Cyclones and Physical processes. Diseases, deterioration, $\mathrm{p}$ sution grazing, agriculture, aquaculture and human encroachment etc., are considered as the thr pogen ic threats to the ecosystem.

5.

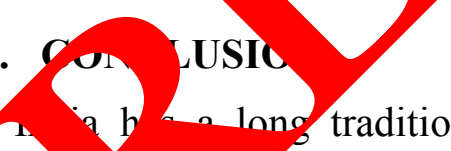

located in Bay or Bengal (partly in India and partly in Bangladesh), were the first mangroves in the world he put under scientific management. The area's first management plan was implemented is 1892. Recognizing the importance of mangroves, the Government of India set up the National Mangrove Committee in the Ministry of Environment and Forests in 1976 to advise the government about mangrove conservation and development. In its first meeting, the panel, which consists of scientists, research scholars and experts on the mangrove ecosystem, emphasized the need to conduct a survey of the extent of existing mangrove areas within the country. The government subsequently introduced a scheme for mangrove conservation and protection, consisting of selection of mangrove areas for conservation, Preparation of a management plan and Adoption of a multidisciplinary approach involving state governments, Universities, research institutions and local organizations. 


\section{References:}

[1] Balachandran, N., and Kichenamourthy S., Diversity of true mangroves and their associates in the Pondicherry region of South India and development of a mangrove knowledgebase. Jour of Ecol and Nat Enviro., 2009, 1, 99-105.

[2] India State of Forest Report, Dehradun, State of Forest Report. Forest Survey of India. 2011, pp. 27-31

[3] Kathiresan , K., How do mangrove forests induce sedimentation? Rev. Biol. Trop., 2003, 51: $355-360$.

[4] Rajkumar, M., and Perumal, R., Phytoplankton diversity in Pichavaram mangrove waters from Southeast Coast. J. Environ. Biol., 2009, 30: 489-498.

[5] Sources: http://www.mangroveindia.org/

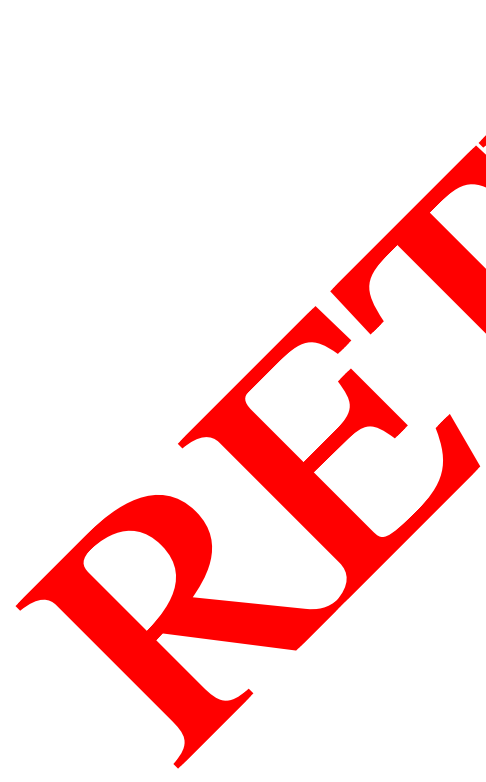

